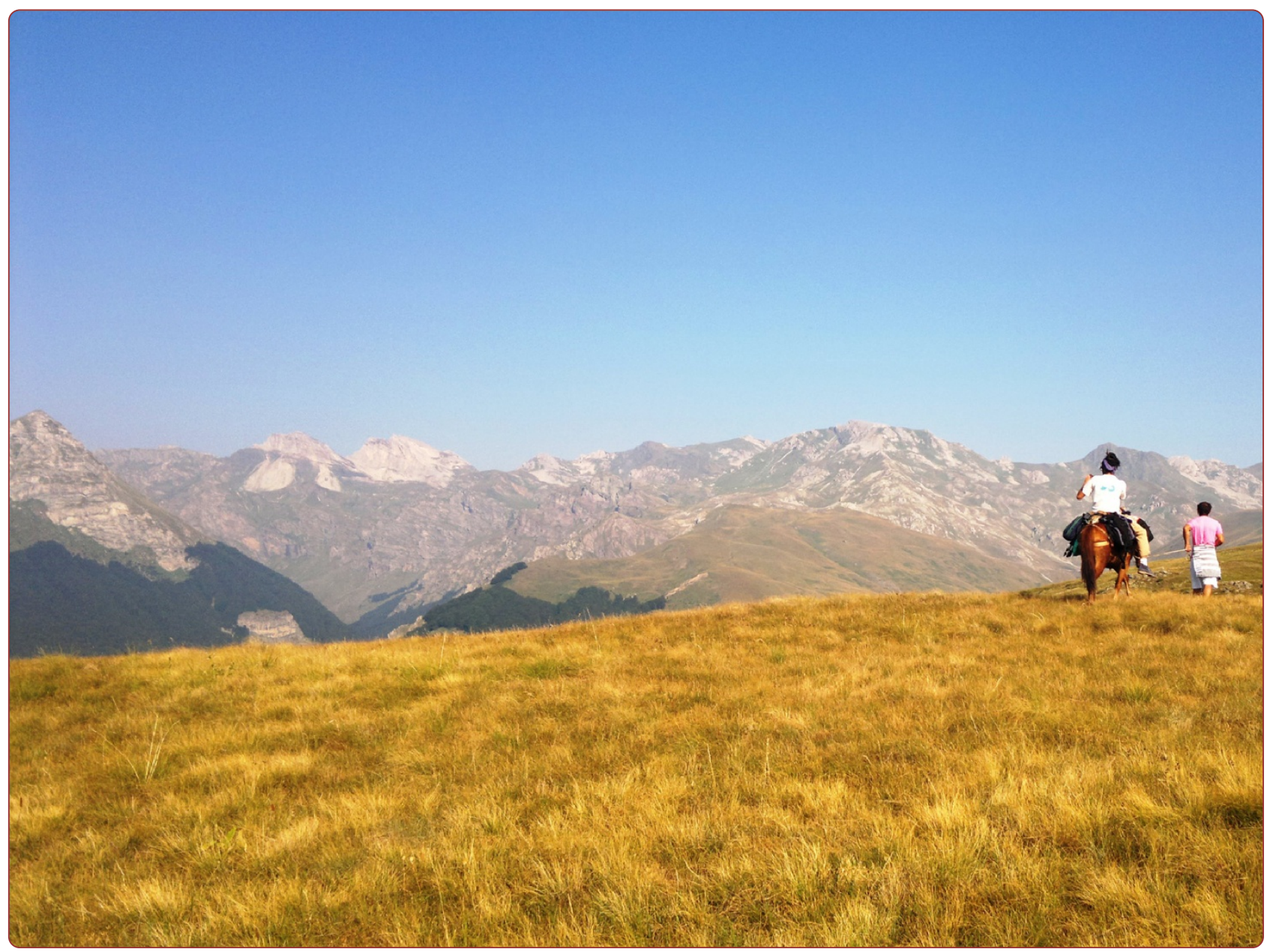

One century later: the folk botanical knowledge of the last remaining Albanians of the upper Reka Valley, Mount Korab, Western Macedonia

Pieroni et al. 


\title{
One century later: the folk botanical knowledge of the last remaining Albanians of the upper Reka Valley, Mount Korab, Western Macedonia
}

\author{
Andrea Pieroni ${ }^{*}$, Besnik Rexhepi ${ }^{2}$, Anely Nedelcheva ${ }^{3}$, Avni Hajdari ${ }^{4}$, Behxhet Mustafa ${ }^{4}$, Valeria Kolosova ${ }^{5}$, \\ Kevin Cianfaglione ${ }^{6}$ and Cassandra L Quave
}

\begin{abstract}
Background: Ethnobotanical surveys of the Western Balkans are important for the cross-cultural study of local plant knowledge and also for obtaining baseline data, which is crucial for fostering future rural development and ecotourism initiatives in the region. The current ethnobotanical field study was conducted among the last remaining Albanians inhabiting the upper Reka Valley at the base of Mount Korab in the Mavrovo National Park of the Republic of Macedonia.

The aims of the study were threefold: 1) to document local knowledge pertaining to plants; 2) to compare these findings with those of an ethnographic account written one century ago and focused on the same territory; and 3) to compare these findings with those of similar field studies previously conducted in other areas of the Balkans.

Methods: Field research was conducted with all inhabitants of the last four inhabited villages of the upper Reka Valley $(n=17)$. Semi-structured and open interviews were conducted regarding the perception and use of the local flora and cultivated plants.

Results and conclusion: The uses of ninety-two plant and fungal taxa were recorded; among the most uncommon uses, the contemporary use of young cooked potato (Solanum tuberosum) leaves and Rumex patientia as a filling for savory pies was documented. Comparison of the data with an ethnographic study conducted one century ago in the same area shows a remarkable resilience of original local plant knowledge, with the only exception of rye, which has today disappeared from the local foodscape. Medicinal plant use reports show important similarities with the ethnobotanical data collected in other Albanian areas, which are largely influenced by South-Slavic cultures.
\end{abstract}

Keywords: Ethnobotany, Mavrovo, Traditional Knowledge, Balkans

\section{Background}

Ethnobiological studies conducted in the Western Balkans in recent years have reported a rich biocultural diversity and a remarkable vitality of traditional knowledge (TK) concerning the local flora in this region [1-12]. Such studies have been postulated to represent crucial lynch-pins for the development of community-based management strategies for local natural resources, sustainable eco-tourism and high-quality niche food and herbal products [13].

\footnotetext{
*Correspondence: a.pieroni@unisg.it

${ }^{1}$ University of Gastronomic Sciences, Piazza Vittorio Emanuele 9, Pollenzo/Bra, (Cuneo) 1-12042, Italy

Full list of author information is available at the end of the article
}

On the other hand, the ethno-historical perspective in the European ethnobotanical literature may represent an important tool for exploring trajectories of changes in plant use, as a few recent works have shown [14-18]. However, the integration of original ethnographic data with historical reports can only take place in those areas in Europe where detailed reports on local uses of plants are available. The comparison of current ethnographic data on plant uses with that reported in ancient treatises on medicinal plants can be more complex and even problematic, as information regarding local plant perceptions cannot generally be traced back. Comparative analysis between the plant knowledge of historical medical

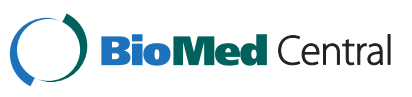


schools and that of subaltern rural classes may, however, be useful for understanding eventual hybridisations of these diverse plant knowledge systems [19-21].

The upper Reka Valley in Western Macedonia represents one of the very few Albanian-speaking areas in South Eastern Europe where a very detailed ethnographic account - including important notes concerning local food and medicinal plant uses - was written in the first decade of the 20th Century. Bajazid Elmaz Doda (approx. 1888-1933) was the personal assistant and long-term partner of one of the most famous scholars in the field of Albanian studies: the Hungarian aristocrat and palaeontologist Baron Franz Nopcsa von Felső-Szilvás (18771933). Doda finalised a manuscript in 1914, probably written in collaboration with his mentor/partner, which was focused on the daily mountain life of his village, Shtirovica, located in the upper Reka Valley (approx. 1400 m.a.s.l.). This manuscript remained unpublished until the Albanologist Robert Elsie found it in the Austrian National Library and edited it in 2007 [22]. Doda apparently wrote this account to challenge the argument of the Serbian-Austrian historian and astronomer Spiridon Gopčević (1855-1928), who described the Albanians of the upper Reka Valley as "albanicised Slavs" [23].

Doda's village of Shtirovica was completely destroyed in 1916 by the Bulgarian army [22]. However, a few surrounding tiny Albanian villages still survive to this day, despite the fact that the local population has been dramatically eroded by recent migration waves, both to the main centres in Macedonia and also abroad.

The aim of this study was to record the traditional plant knowledge of the last remaining Albanians living in these villages of the upper Reka Valley and to compare this with the ethnobotanical notes found in Doda's work in order to better understand trajectories of change in plant uses. Moreover, a further objective of the study was to compare this field data with that of other recent ethnobotanical surveys conducted in surrounding areas and countries in order to trace commonalities and similarities, and to address overlaps and divergences in Albanian and South-Slavic traditional plant knowledge and practice.

\section{Methods}

\section{Field study}

In-depth open and semi-structured interviews, as well as participant observation were conducted in August 2012 with members $(n=17)$ of all remaining families of the last inhabited villages of the upper Reka Valley (Figure 1): Nistrovë, Bibaj, Niçpur, and Tanushaj, within the Mavrovo National Park. The same villages were inhabited a few decades ago by hundreds of locals, who mostly migrated to the nearby towns of Gostivar and Skopje, as well as abroad for work or (as in Tanushaj) as a consequence of a (minor) Macedonian portion of the last Yugoslavian Wars.

Locals are now exclusively Muslims, but Albanians of Christian Orthodox faith also lived in the villages until a

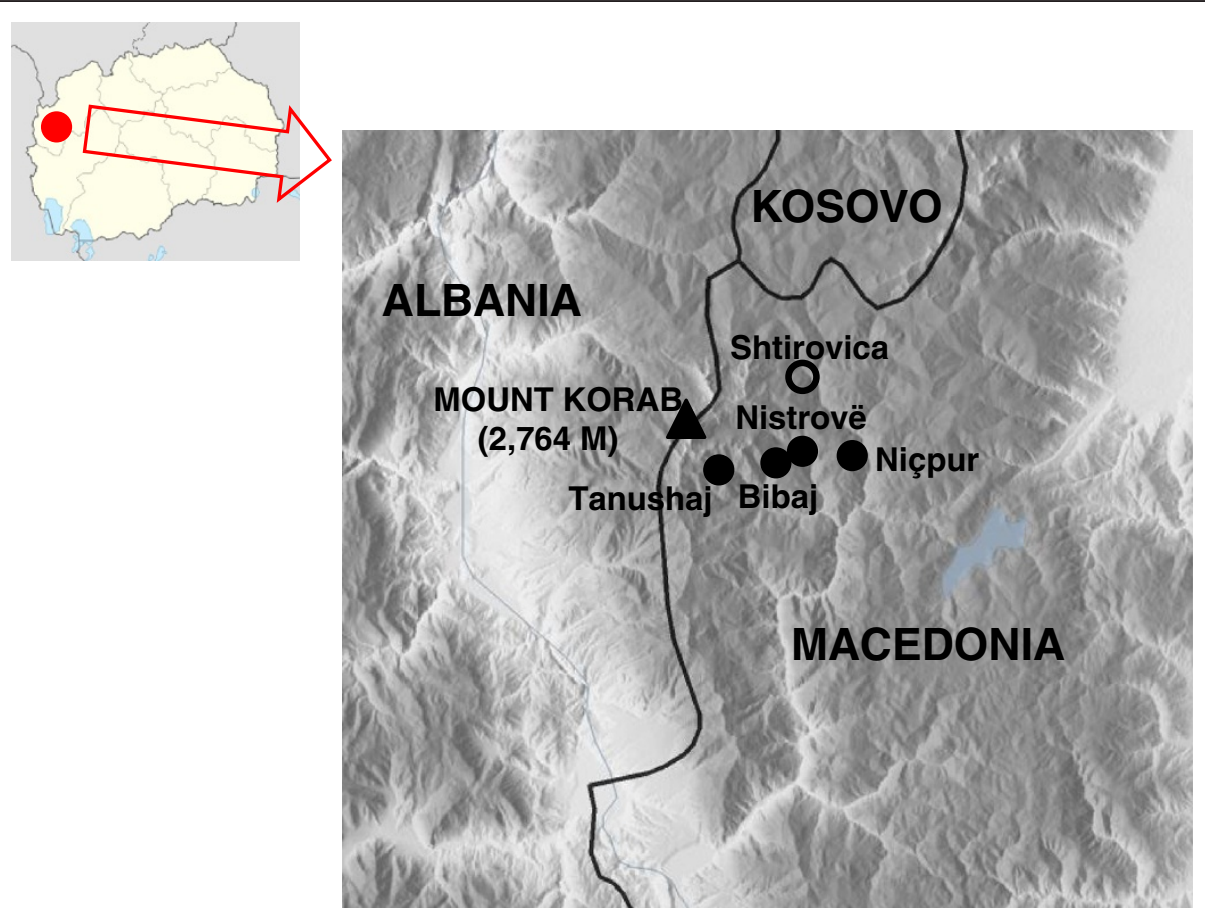

Figure 1 Study area. 
few decades ago. For example, in Nistrovë, one side of the village (with a mosque) is inhabited by Muslims, while the other side was inhabited by Orthodox believers. The entire population of Orthodox Christians migrated to towns a few decades ago, but they return to their village homes sometimes during the summer. Most of the houses in this part of the village are however abandoned even though the Church has been recently restored. According to our (Albanian Muslim) informants, these migrated Orthodox Christian Albanians assimilated within the Macedonian culture and now prefer to be labelled as "Macedonians", even if they are still able to fluently speak Albanian. Contact between these two subsets of the village communities, which were very intense and continuous in the past, no longer exists today.

All Albanian inhabitants of the upper Reka are - to different degrees depending on the age - bilingual in Macedonian. Participants were questioned about traditional uses of medicinal plants and wild food plants (in use until a few decades ago or still in use today). Specifically, data concerning the local name(s) of each quoted taxon, the plant part(s) used, in-depth details about its/their manipulation/preparation and medicinal or food use(s) were collected. Interviews were conducted in Albanian with the help of two simultaneous translators.

Prior informed consent was always obtained verbally before conducting interviews and researchers adhered to the new ethical guidelines of the American Anthropological Association [24]. During interviews, informants were always asked to show the quoted plants. Voucher specimens of the most uncommon wild taxa, as well as digital pictures of the most quoted preparations were taken and are deposited at the University of Tetovo and at the University of Gastronomic Sciences, respectively. A short video documentation of the field study is available online [25].

Taxonomic identification was conducted by the first author and plant nomenclature follows Flora Europaea [26], the Angiosperm Phylogeny Group III system [27] and The Plant List database [28]. The collected data was compared with Bajazid Elmaz Doda's ethnographic study, which was conducted one century ago in the village of Shtirovica (Figure 1), within the same study area of our survey [22], and with the most relevant recent Balkan ethnobotanical field studies [1,8-10,13,29-33] and the other available South-Slavic linguistic and folkloricbotanical sources [22,34-44].

\section{Results and discussion}

The current ethnobotanical knowledge of the upper Reka Table 1 reports the plant uses recorded in the upper Reka Valley. Ninety-two taxa were reported to be known and in use by the last remaining inhabitants, who were all interviewed. The resilience of the local traditional knowledge concerning plants is especially remarkable when compared with the recordings of the local plant knowledge documented one century ago (see last column of the table [22]). A few of the plant uses (with the exception of rye) recorded one century ago are still actively practiced today in the upper Reka Valley.

This seems to contradict what Bajazid Elmaz Doda postulated in his ethnographic report about the possible disappearance of the Albanians and their cultural heritage in the upper Reka [22], where an important folk medical heritage, although dramatically eroded, is still occurring. Among the most uncommon plant uses, the most noteworthy is the continuation of the use of the young leaves of cultivated potatoes and of wild Rumex patientia as filling for home-made savory pies. To the best of our knowledge, the recording of a food use of aerial parts of potatoes is new in contemporary Europe and may be explained by the extreme poverty and scarcity of resources in this mountainous area, even in the context of the Western Balkans. A confirmation of this phenomenon is perhaps best illustrated by the migration trends from the upper Reka to Romania and Istanbul (mainly of young men), beginning in the 19th Century [22]. In another study conducted on the Albanian side of Mount Korab (unpublished data), elderly locals confirmed that the upper Reka villages on the (current day) Macedonian side of the mountain were well known to them even in the folk history for being extremely disadvantaged in terms of socio-economic conditions.

\section{The linguistic features of the current ethnobotanical knowledge of the upper Reka Valley}

In Table 1, the folk plant names that were recorded in the upper Reka Valley and which are also used by South Slavs are denoted by an asterisk. Approximately one-third of the recorded pythonyms are also used by the South Slavs, with some notable examples of Slavic etymology concerning culturally-important and very commonly used wild plants, such as Urtica dioica, Hypericum perforatum, and Primula veris, as well as most cultivated crops and some forest trees too.

\section{Wild gentian vs. the white hellebore: a surprising cognitive "inversion"}

In the study area, the linguistic labels of gentian (Gentiana lutea) and white hellebore (Veratrum album) are the same. Gentian is, in fact, locally named as wild (meaning here "looking-like") white hellebore (shtarë). This contradicts what would be expected regarding the plant cognitive prototype, which generally is represented by the most culturally salient or mostly used folk species [45], which in the Balkans is surely gentian. Instead, here gentian has been largely gathered solely for trade in the 
Table 1 Folk names and uses of plants and fungi quoted in the current study, compared with those recorded one century ago in the same area

\begin{tabular}{|c|c|c|c|c|c|}
\hline Scientific taxon and family & $\begin{array}{l}\text { Local folk } \\
\text { name(s) }\end{array}$ & $\begin{array}{l}\text { Ecological status } \\
\text { or provenience }\end{array}$ & Part(s) used & Local use(s) & $\begin{array}{l}\text { Folk name(s) and use(s) as recorded one } \\
\text { century ago in the same area [22] }\end{array}$ \\
\hline $\begin{array}{l}\text { Abies alba Mill. and Picea abies } \\
\text { (L.) H. Karst. (Pinaceae) }\end{array}$ & Bren & W & Resin $\left(s m o{ }^{*}\right)$ & $\begin{array}{l}\text { MEDICINAL: topically applied to wounds, } \\
\text { sometimes together with tobacco (as } \\
\text { haemostatic) or on warts }\end{array}$ & $\begin{array}{l}\text { Breh MEDICINAL: resin }(\mathrm{smo} / *) \text { as an ingredient } \\
\text { of a home-made poultice }(\text { mehlem) - made also } \\
\text { by adding wax, fat, and powdered pine wood - } \\
\text { for treating wounds }\end{array}$ \\
\hline \multirow[t]{2}{*}{$\begin{array}{l}\text { Acer pseudoplatanus } \\
\text { L. (Sapindaceae) }\end{array}$} & $\begin{array}{l}\text { Klenje }^{*} \\
\text { Kleni* }^{*}\end{array}$ & W & Wood & $\begin{array}{l}\text { HANDICRAFTS: diverse objects, among } \\
\text { them, snow shoes }\end{array}$ & Pani \\
\hline & & & Bark & $\begin{array}{l}\text { VETERINARY: decoction, in external washes } \\
\text { for treating wounds in animals }\end{array}$ & \\
\hline $\begin{array}{l}\text { Achillea millefolium } \\
\text { L. (Asteraceae) }\end{array}$ & $\begin{array}{l}\text { Lule e bardhë } \\
\text { Lule miu }\end{array}$ & W & $\begin{array}{l}\text { Dried flowering aerial } \\
\text { parts }\end{array}$ & $\begin{array}{l}\text { MEDICINAL: tea, considered healthy for } \\
\text { stomach-ache and liver problems; traded } \\
\text { in the past }\end{array}$ & \\
\hline $\begin{array}{l}\text { Allium cepa } \\
\text { L. (Amaryllidaceae) }\end{array}$ & Qepa & C & Bulbs & $\begin{array}{l}\text { FOOD: many culinary uses, including home- } \\
\text { made savory pies called ndri, filled with } \\
\text { buttermilk (dhallët) and diverse vegetables; } \\
\text { MEDICINAL: compresses made with crushed } \\
\text { onions and salt for treating bruises } \\
\text { RITUAL: burned on the fire }\end{array}$ & $\begin{array}{l}\text { Qep FOOD: filling for savory pies } \\
\text { MEDICINAL: externally applied with salt } \\
\text { on wounds }\end{array}$ \\
\hline \multirow[t]{2}{*}{ Allium porrum L. (Amaryllidaceae) } & Prash $^{*}$ & C & Fresh aerial parts & $\begin{array}{l}\text { FOOD: filling for home-made savory pies } \\
\text { (ndri) }\end{array}$ & Prasa \\
\hline & & & Juice & $\begin{array}{l}\text { MEDICINAL: instilled in the ear for treating } \\
\text { ear-ache }\end{array}$ & \\
\hline \multirow[t]{2}{*}{ Allium sativum L. (Amaryllidaceae) } & Hudra & C & Bulbs & FOOD: seasoning & Hudr \\
\hline & & & & $\begin{array}{l}\text { RITUAL: burned on the fire; the resulting } \\
\text { strong odour was considered a repellent for } \\
\text { werewolves; tied to cow horns as a } \\
\text { protective amulet against evil-eye }\end{array}$ & \\
\hline $\begin{array}{l}\text { Alnus glutinosa } \\
\text { (L.) Gaertn. (Betulaceae) }\end{array}$ & Verri & W & Bark & $\begin{array}{l}\text { DYEING: the bark was boiled in the past; the } \\
\text { resulting red decoction was used for dyeing } \\
\text { in black }\end{array}$ & Verri \\
\hline $\begin{array}{l}\text { Amaranthus spp. } \\
\text { (Amaranthaceae) }\end{array}$ & Llabot e egër & W & Leaves & FODDER & \\
\hline Arctium lappa L. (Asteraceae) & Kakuda & W & Leaves & FODDER & \\
\hline $\begin{array}{l}\text { Atriplex hortensis } \mathrm{L} . \\
\text { (Amaranthaceae) }\end{array}$ & $\begin{array}{l}\text { Laboda* }^{*} \\
\text { Labat* }^{*}\end{array}$ & C & Leaves & FOOD: most preferred filling for pies (ndri) & \\
\hline Betula pendula Roth (Betulaceae) & Mustekna & W & Bark & $\begin{array}{l}\text { MEDICINAL: burned; the vapours are } \\
\text { exposed to the skin for treating skin } \\
\text { inflammations } \\
\text { HANDICRAFTS: brooms }\end{array}$ & Mushtekn \\
\hline
\end{tabular}


Table 1 Folk names and uses of plants and fungi quoted in the current study, compared with those recorded one century ago in the same area (Continued)

\begin{tabular}{|c|c|c|c|c|c|}
\hline Boletus spp. (Boletaceae) & $\begin{array}{l}\text { Këpurdha } \\
\text { (Varganj*) }\end{array}$ & W & Fresh fruiting body & $\begin{array}{l}\text { FOOD: stored dried and sold to middle } \\
\text { men; traditionally it was not consumed, } \\
\text { nowadays is sometimes used in omelettes } \\
\text { with eggs and cheese, or as a filling for } \\
\text { savory pies }\end{array}$ & \\
\hline $\begin{array}{l}\text { Brassica oleracea } \\
\text { L. (Brassicaceae) }\end{array}$ & Lakna & C & Leaves & FOOD: in diverse preparations & $\begin{array}{l}\text { Lakna FOOD: filling for savory pies; } \\
\text { lactofermented, in sarma (sauerkraut leaves } \\
\text { filled with rice and meat) or minced in salads }\end{array}$ \\
\hline $\begin{array}{l}\text { Calamintha officinalis } \\
\text { Mill. (Lamiaceae) }\end{array}$ & & W & Fresh leaves & $\begin{array}{l}\text { MEDICINAL: externally applied to treat } \\
\text { toothache }\end{array}$ & \\
\hline $\begin{array}{l}\text { Cantharellus cibarius } \\
\text { Fr. (Cantharellaceae) }\end{array}$ & $\begin{array}{l}\text { Kepurdha } \\
\text { (Lisiçarka*) }\end{array}$ & W & Fruiting body & $\begin{array}{l}\text { FOOD: consumed fried with eggs and } \\
\text { clarified butter }\end{array}$ & \\
\hline \multirow[t]{4}{*}{$\begin{array}{l}\text { Capsicum annuum } \\
\text { L. (Solanaceae) }\end{array}$} & $\begin{array}{l}\text { Spec } \\
\text { (sweet varieties) }\end{array}$ & C & Dried fruits & $\begin{array}{l}\text { FOOD: as a vegetable, fried; mixed with } \\
\text { ricotta (gjizë) and consumed after a few } \\
\text { weeks; ground, as one of the ingredients of } \\
\text { the home-made seasoning mixture called } \\
\text { piprik e shtupun, prepared by mixing ground } \\
\text { red peppers, chilli, pumpkin seeds, corn } \\
\text { flour, mint, and salt (traditionally consumed } \\
\text { on boiled potatoes or warm bread) }\end{array}$ & Spec \\
\hline & $\begin{array}{l}\text { Piprik }^{*} \\
\text { (hot varieties) }\end{array}$ & C & Dried fruits & $\begin{array}{l}\text { FOOD: ingredient of the spice mix piprike } \\
\text { shtupun (see above) }\end{array}$ & \\
\hline & & & & $\begin{array}{l}\text { MEDICINAL: ground and mixed with clarified } \\
\text { butter or pork fat in a poultice, which is } \\
\text { externally applied against rheumatisms }\end{array}$ & \\
\hline & & & & $\begin{array}{l}\text { RITUAL: burned on the fire; the resulting } \\
\text { strong odour is considered a repellent for } \\
\text { werewolves (lugata) }\end{array}$ & \\
\hline $\begin{array}{l}\text { Carlina acanthifolia All. } \\
\text { (Asteraceae) }\end{array}$ & $\begin{array}{l}\text { Thera } \\
\text { Kaçani* }\end{array}$ & W & Fresh flower receptacles & FOOD: consumed raw as snacks & \\
\hline $\begin{array}{l}\text { Carpinus betulus } \\
\text { L. (Betulaceae) }\end{array}$ & Dru kaprivë & W & Wood & $\begin{array}{l}\text { HANDICRAFTS: diverse agricultural tools, } \\
\text { including sickles }\end{array}$ & \\
\hline $\begin{array}{l}\text { Carpinus orientalis } \\
\text { Mill. (Betulaceae) }\end{array}$ & Gaber* & W & Bark & $\begin{array}{l}\text { VETERINARY: decoction, in external washed } \\
\text { on cuts }\end{array}$ & \\
\hline $\begin{array}{l}\text { Cetraria islandica } \\
\text { (L.) Ach. (Parmeliaceae) } \\
\end{array}$ & Mishk & W & Thallus & MEDICINAL: gathered and traded in the past & \\
\hline $\begin{array}{l}\text { Chenopodium bonus-henricus } \\
\text { L. (Amarathaceae) }\end{array}$ & Çuen* & W & Roots & $\begin{array}{l}\text { FOOD: used in the past for making home- } \\
\text { made halva* (Ottoman sweet prepared by } \\
\text { gently stirring the decotion obtained by } \\
\text { boiling these roots in water, with wheat } \\
\text { and/or corn flour for one hour, and } \\
\text { generally adding walnuts or raisins at the } \\
\text { end, and letting it cool/solidify); the roots } \\
\text { were also traded in the past }\end{array}$ & $\begin{array}{l}\text { Çuen FOOD: home-made production of the } \\
\text { sweet halva, made by cooking together roots, } \\
\text { sugar syrup and powdered nuts - roots of çuen } \\
\text { were erroneously identified by Doda as those of } \\
\text { Saponaria spp. Upper Reka men were famous } \\
\text { halva-sellers }\end{array}$ \\
\hline
\end{tabular}


Table 1 Folk names and uses of plants and fungi quoted in the current study, compared with those recorded one century ago in the same area (Continued)

\begin{tabular}{|c|c|c|c|c|c|}
\hline $\begin{array}{l}\text { Citrullus lanatus (Thunb.) Mansf. } \\
\text { (Cucurbitaceae) }\end{array}$ & $\begin{array}{l}\text { Bostan } \\
\text { Lubenicë* }\end{array}$ & B & Fruit pulp & $\begin{array}{l}\text { FOOD/MEDICINAL: consumed raw, } \\
\text { considered a means for cleansing the } \\
\text { intestines }\end{array}$ & \\
\hline \multirow[t]{3}{*}{$\begin{array}{l}\text { Clematis vitalba L. } \\
\text { (Ranunculaceae) }\end{array}$} & $\begin{array}{l}\text { Kurpna } \\
\text { Pofit* }\end{array}$ & W & Branches & $\begin{array}{l}\text { HANDICRAFTS: traditionally weaved in } \\
\text { baskets used for bee-keeping }\end{array}$ & \\
\hline & & & Fresh flowers & HONEY PLANT & \\
\hline & & & (Dried?) flowers & FOOD: used in the past as bread yeast & \\
\hline Cornus mas L. (Cornaceae) & Thona & W & Fresh fruits & $\begin{array}{l}\text { FOOD: consumed raw; } \\
\text { FOOD/MEDICINAL: syrups and distillate } \\
\text { (raki thonet) considered healthy, } \\
\text { esp. for treating fever }\end{array}$ & Thon \\
\hline \multirow[t]{2}{*}{ Corylus avellana L. (Betulaceae) } & Leithiza & W & Kernels & FOOD: consumed raw as snacks & Leithi \\
\hline & & & Branches & $\begin{array}{l}\text { OTHERS: as structural supports for bean } \\
\text { plants in the vegetable garden }\end{array}$ & \\
\hline \multirow[t]{2}{*}{$\begin{array}{l}\text { Crataegus monogyna Jacq. var. } \\
\text { sericea Dzekov (Rosaceae) }\end{array}$} & Murrisi & W & Dried flowers & MEDICINAL: tea, as an anti-hypertensive & $\begin{array}{l}\text { Muris geni RITUAL: child affected by measles } \\
\text { was placed under a hawthorn plant and water } \\
\text { was thrown on him/her }\end{array}$ \\
\hline & & & Fruits & $\begin{array}{l}\text { FOOD: consumed as snack and in syrups } \\
\text { and jams }\end{array}$ & \\
\hline $\begin{array}{l}\text { Cucumis sativus L. } \\
\text { (Cucurbitaceae) }\end{array}$ & Kastraveca* & C & Fruits & $\begin{array}{l}\text { FOOD: consumed raw, or, more often, } \\
\text { lactofermented (turshi*) }\end{array}$ & \\
\hline \multirow{2}{*}{$\begin{array}{l}\text { Cucurbita maxima Duchesne } \\
\text { (Cucurbitaceae) }\end{array}$} & Kungulla & C & Fruits & FOOD: filling for pies & Kungul FOOD: filling for pies (ndri) \\
\hline & & & Dried seeds & $\begin{array}{l}\text { FOOD: consumed as snacks; ground and } \\
\text { used as an ingredient of the home-made } \\
\text { seasoning mixture piprik e shtupun (see } \\
\text { Capsicum annuum) }\end{array}$ & \\
\hline Euphorbia sp. (Euphorbiaceae) & Lule gjarpi & W & Aerial parts & $\begin{array}{l}\text { OTHERS: crushed and used for fishing trout } \\
\text { (pastërmka) in the river (as a fish poison) }\end{array}$ & Lishanj \\
\hline \multirow[t]{3}{*}{ Fagus sylvatica L. (Fagaceae) } & Ahu & W & $\begin{array}{l}\text { Fresh young leaves and } \\
\text { kernels }\end{array}$ & FOOD: consumed as a snack in the past & $A h$ \\
\hline & & & Branches and wood & FUEL & \\
\hline & & & & $\begin{array}{l}\text { HANDICRAFTS: fences, diverse agricultural } \\
\text { tools, "skeleton" of horse saddles and barns }\end{array}$ & \\
\hline $\begin{array}{l}\text { Fomes fomentarius } \\
\text { (L.) J. J. Kickx (Polyporaceae) }\end{array}$ & Eshka & W & Dried fruiting body & $\begin{array}{l}\text { OTHERS: burned; the resulting smoke is used } \\
\text { to keep away bees while gathering honey }\end{array}$ & \\
\hline Fragaria vesca L. (Rosaceae) & Drezdha & W & Fruits & FOOD: consumed raw & Drethsa \\
\hline Fraxinus excelsior L. (Oleaceae) & Frashëri & W & Wood & HANDICRAFTS: for building flutes (kaval*) & \\
\hline Gentiana lutea L. (Gentianaceae) & Shtarë e egëra & W & Roots & $\begin{array}{l}\text { MEDICINAL: largely gathered and traded in } \\
\text { the past; use unknown }\end{array}$ & Shatra e egër \\
\hline
\end{tabular}


Table 1 Folk names and uses of plants and fungi quoted in the current study, compared with those recorded one century ago in the same area (Continued)

\begin{tabular}{|c|c|c|c|c|c|}
\hline Helleborus spp. (Ranunculaceae) & Kukurek* & W & Roots & $\begin{array}{l}\text { MEDICINAL: inserted in the horse's breast for } \\
\text { treating muscular blocks (horses not able to } \\
\text { be ridden anymore) }\end{array}$ & $\begin{array}{l}\text { Kukurek VETERINARY: inserted into the } \\
\text { nose to treat nasal congestion in horses }\end{array}$ \\
\hline $\begin{array}{l}\text { Helichrysum plicatum DC. } \\
\text { (Asteraceae) }\end{array}$ & Lule për molca & W & Dried flowering tops & $\begin{array}{l}\text { OTHERS: placed in the closets as a moth } \\
\text { repellent }\end{array}$ & \\
\hline Hordeum vulgare L. (Poaceae) & Elb & C & Fruits & $\begin{array}{l}\text { FOOD: consumed in the past in gruels } \\
\text { with corn; } \\
\text { FODDER for sheep }\end{array}$ & Elb \\
\hline Hyosciamus niger L. (Solanaceae) & & W & Dried flowers & $\begin{array}{l}\text { MEDICINAL: burned and the smoke exposed } \\
\text { to the mouth to treat toothache (in the past) }\end{array}$ & \\
\hline \multirow[t]{2}{*}{$\begin{array}{l}\text { Hypericum perforatum } \\
\text { L. (Hypericaceae) }\end{array}$} & $\begin{array}{l}\text { Katrion* } \\
\text { Kantarion* } \\
\text { Çaj bistrë } \\
\text { Lule e verdhë }\end{array}$ & W & Dried flowering tops & $\begin{array}{l}\text { MEDICINAL: tea, for treating kidney stones, } \\
\text { colds, stomach-ache, rheumatisms (used } \\
\text { every day for at least a few months) or } \\
\text { simply drunk as a "healthy" beverage; } \\
\text { topically applied for treating wounds }\end{array}$ & \\
\hline & & & Fresh flowering tops & $\begin{array}{l}\text { MEDICINAL: Macerate in oil (obtained by } \\
\text { exposing it in the sun for several weeks) or } \\
\text { prepare as a tea externally applied for } \\
\text { treating skin burns, cuts, or other skin } \\
\text { inflammations }\end{array}$ & \\
\hline \multirow[t]{2}{*}{ Juglans regia L. (Juglandaceae) } & Arra & SD & Kernels & $\begin{array}{l}\text { FOOD: used for cakes; a specific pie (ndri) } \\
\text { was prepared with walnuts and lamb meat, } \\
\text { and consumed on feast days }\end{array}$ & Arr \\
\hline & & & Unripe fruits & $\begin{array}{l}\text { FOOD/MEDICINAL: dipped in honey (and } \\
\text { eventually lemon juice), the resulting } \\
\text { preserve is considered healthy against } \\
\text { tuberculosis and bronchitis }\end{array}$ & \\
\hline \multirow[t]{2}{*}{$\begin{array}{l}\text { Juniperus communis } \\
\text { L. (Cupressaceae) }\end{array}$} & Dëllinia & W & Galbules & $\begin{array}{l}\text { FOOD: seasoning } \\
\text { MEDICINAL: tea, for treating cough, } \\
\text { rheumatisms and "good for the blood"; } \\
\text { largely gathered and sold, especially } \\
\text { in the past }\end{array}$ & Dulinj \\
\hline & & & Dried bark & OTHERS: smoked as a tobacco substitute & \\
\hline Lactuca sativa L. (Asteracaeae) & Marolla* & C & Fresh leaves & FOOD: salads & \\
\hline $\begin{array}{l}\text { Lycopersicon esculentum } \\
\text { Mill. (Solanaceae) }\end{array}$ & Patlixhan* & C & Fresh fruits & FOOD & Patlingjan kuq \\
\hline \multirow[t]{2}{*}{$\begin{array}{l}\text { Malus domestica } \\
\text { Borkh. (Rosaceae) }\end{array}$} & Molla & SD & Fruits & $\begin{array}{l}\text { FOOD/MEDICINAL: traditionally consumed } \\
\text { raw, or roasted, or in pies or jams; the fruits } \\
\text { of the most acidic landraces were used for } \\
\text { producing home-made vinegar (adding } \\
\text { water and letting ferment for } 40 \text { days) - this } \\
\text { vinegar is considered healthy for treating } \\
\text { hypertension }\end{array}$ & Moll \\
\hline & & & Fruits $\rightarrow$ Raki & $\begin{array}{l}\text { MEDICINAL: drunk as a stimulant } \\
\text { (anti-lethargic) }\end{array}$ & \\
\hline
\end{tabular}


Table 1 Folk names and uses of plants and fungi quoted in the current study, compared with those recorded one century ago in the same area (Continued)

\begin{tabular}{|c|c|c|c|c|c|}
\hline $\begin{array}{l}\text { Matricaria recutita } \\
\text { L. (Asteraceae) }\end{array}$ & Kamomila & W & $\begin{array}{l}\text { Dried flowering aerial } \\
\text { parts }\end{array}$ & $\begin{array}{l}\text { MEDICINAL: tea for treating toothache, } \\
\text { stomach-ache and belly pains (esp. in } \\
\text { babies) }\end{array}$ & Cfarlik \\
\hline Medicago sativa L. (Fabaceae) & Jonxhe & C & Aerial parts & FODDER & \\
\hline Melissa officinalis L. (Lamiaceae) & Milc & W & Fresh flowers & $\begin{array}{l}\text { HONEY PLANT: considered the best honey } \\
\text { plant }\end{array}$ & \\
\hline $\begin{array}{l}\text { Mentha longifolia } \\
\text { (L.) Huds. (Lamiaceae) }\end{array}$ & Nagjas i egër & W & Dried flowering tops & $\begin{array}{l}\text { MEDICINAL: tea, as a stimulant (considered } \\
\text { poisonous if drunk in large amounts) }\end{array}$ & \\
\hline \multirow[t]{2}{*}{ Mentha spicata L. (Lamiaceae) } & $\begin{array}{l}\text { Nane } \\
\text { Nagjas }\end{array}$ & W and $C$ & Dried leaves & $\begin{array}{l}\text { FOOD: ground, used as an ingredient of the } \\
\text { seasoning mix piprik e shtupun (see } \\
\text { Capsicum annuum) }\end{array}$ & \\
\hline & & & & $\begin{array}{l}\text { MEDICINAL: tea, for treating stomach and } \\
\text { intestinal pains, esp. in children, or as an } \\
\text { anti-diarrhoeal }\end{array}$ & \\
\hline $\begin{array}{l}\text { Nicotiana tabacum } \\
\text { L. (Solanaceae) }\end{array}$ & $\begin{array}{l}\text { Duhan* } \\
\text { Tutun* }\end{array}$ & B & Dried crashed leaves & $\begin{array}{l}\text { VETERINARY: externally applied on wounds } \\
\text { or skin problems in sheep }\end{array}$ & $\begin{array}{l}\text { MEDICINAL: external applications for treating } \\
\text { wounds (mixed with honey) }\end{array}$ \\
\hline Orchis spp. (Orchidaceae) & $\begin{array}{l}\text { Salep* } \\
\text { (two quoted } \\
\text { "folk specifics": } \\
\text { one showing pink } \\
\text { flowers and the } \\
\text { other one with } \\
\text { yellow flowers) }\end{array}$ & W & Dried tubers & $\begin{array}{l}\text { MEDICINAL: ground, and then mixed with } \\
\text { milk and dried again; the resulting powder } \\
\text { is used in teas, as a "healthy" beverage } \\
\text { (rarely macerated in plum distillate and } \\
\text { drunk as a medicine); in the past largely } \\
\text { gathered and sold }\end{array}$ & $\begin{array}{l}\text { Broçka Salep FOOD: powdered orchid tubers } \\
\text { were stirred with warm water and sugar; many } \\
\text { young men from the upper Reka left their } \\
\text { homes to work as salep, bosa and halva sellers } \\
\text { in Skopje, Istanbul, Romania, and Bulgaria }\end{array}$ \\
\hline $\begin{array}{l}\text { Origanum vulgare } \\
\text { L. (Lamiaceae) }\end{array}$ & $\begin{array}{l}\text { Çaj } \\
\text { Çaj i malit } \\
\text { Çaj i livadhi* }\end{array}$ & W & $\begin{array}{l}\text { Dried flowering aerial } \\
\text { parts }\end{array}$ & $\begin{array}{l}\text { MEDICINAL: tea for treating sore throat, } \\
\text { cough, heart problems, intestinal } \\
\text { discomforts, or as a recreational beverage }\end{array}$ & \\
\hline $\begin{array}{l}\text { Petasites hybridus } \\
\text { (L.) Gaertn. (Asteraceae) }\end{array}$ & Kakuda Lapua & W & Leaves & FODDER & Kakuda \\
\hline Phaseolus vulgaris L. (Fabaceae) & Grosha* & $\begin{array}{l}\mathrm{C} \text { (brown and } \\
\text { white landraces) }\end{array}$ & Dried seeds & FOOD: soups & $\begin{array}{l}\text { Grosh FOOD: boiled, generally cooked together } \\
\text { fresh or dried meat, adding bone marrow (galgo) }\end{array}$ \\
\hline Pisum sativum L. (Fabaceae) & Grashaka* & C & Seeds & FOOD: cooked with meat or potatoes & Nahut \\
\hline $\begin{array}{l}\text { Plantago major } \mathrm{L} \text {. } \\
\text { (Plantaginaceae) }\end{array}$ & Lule deli & W & Leaves & $\begin{array}{l}\text { MEDICINAL: tea, for treating kidney stones; } \\
\text { externally applied for treating cuts }\end{array}$ & $\begin{array}{l}\text { Bajsht delit MEDICINAL: external applications of } \\
\text { leaves and roots for treating furuncles }\end{array}$ \\
\hline Primula veris L. (Primulaceae) & Gornicfet* & W & Flowers & $\begin{array}{l}\text { MEDICINAL: sold and traded in the past - } \\
\text { use unknown }\end{array}$ & Garicfet \\
\hline Prunus avium L. (Rosaceae) & Shurshia & SD & Fresh fruits & FOOD: consumed raw; syrups & Qershi \\
\hline \multirow[t]{2}{*}{ Prunus cerasus L. (Rosaceae) } & Vishnja* & SD & Fruits & FOOD: consumed raw, or dried, or in syrups & Vishnja \\
\hline & & & $\operatorname{Resin}\left(s m o l^{*}\right)$ & $\begin{array}{l}\text { MEDICINAL: externally applied on skin } \\
\text { inflammations }\end{array}$ & \\
\hline $\begin{array}{l}\text { Prunus cerasus L. var. marasca } \\
\text { (Host.) Viv. (Rosaceae) }\end{array}$ & Shurshia e egër & SD & Fruits & FOOD: consumed raw or dried, or in syrups & \\
\hline
\end{tabular}


Table 1 Folk names and uses of plants and fungi quoted in the current study, compared with those recorded one century ago in the same area (Continued)

\begin{tabular}{|c|c|c|c|c|c|}
\hline Prunus domestica L. (Rosaceae) & $\begin{array}{l}\text { Kumbulla } \\
\text { Gjagalka }\end{array}$ & $\begin{array}{l}\text { SD (many diverse } \\
\text { landraces, with } \\
\text { yellow, red, and } \\
\text { black fruits) }\end{array}$ & Fruits & $\begin{array}{l}\text { FOOD: consumed raw or dried; cooked with } \\
\text { sugar and dried, and consumed as candies; } \\
\text { hoshaf* - thickened fruit juice preserve; it is } \\
\text { diluted with water (and eventually sugar) } \\
\text { and drunk }\end{array}$ & Kumla \\
\hline & & & $\begin{array}{l}\text { Fresh fruits (fermented } \\
1-2 \text { months and then } \\
\text { resulting must } \\
\text { distilled) } \rightarrow \text { raki* }\end{array}$ & $\begin{array}{l}\text { MEDICINAL: instilled in the ear for treating } \\
\text { earaches; drunk as a "healthy" beverage for } \\
\text { the heart (rare) or to counteract tiredness; } \\
\text { externally applied as a disinfectant for } \\
\text { wounds }\end{array}$ & $\begin{array}{l}\text { MEDICINAL: distillate externally applied on } \\
\text { bullet wounds }\end{array}$ \\
\hline Pyrus communis L. (Rosaceae) & Dardha & W & Fresh fruits & FOOD: consumed raw & Dardha \\
\hline Rhamnus alpina L. (Rhamnaceae) & & W & Fruits & FOOD: consumed as snacks & \\
\hline $\begin{array}{l}\text { Robinia pseudoacacia } \\
\text { L. (Fabaceae) }\end{array}$ & Bagrem* & W & Fresh flowers & $\begin{array}{l}\text { HONEY PLANT: the resulting honey is } \\
\text { considered effective against cough }\end{array}$ & \\
\hline \multirow[t]{2}{*}{ Rosa canina L. (s.I.) (Rosaceae) } & $\begin{array}{l}\text { Kaça } \\
\text { Shipinka* }\end{array}$ & W & Fresh fruits & FOOD: jams & Kaç \\
\hline & & & Dried fruits & $\begin{array}{l}\text { MEDICINAL: tea, for treating cold, fever, } \\
\text { cough }\end{array}$ & \\
\hline \multirow[t]{2}{*}{ Rubus idaeus L. (Rosaceae) } & $\begin{array}{l}\text { Medra } \\
\text { Mjedra } \\
\text { Malina* }\end{array}$ & W & Fresh fruits & $\begin{array}{l}\text { FOOD/MEDICINAL: consumed raw; syrup } \\
(\text { sok*) and hoshaf* (dense thickened juice, } \\
\text { diluted with water and drunk) are } \\
\text { considered healthy }\end{array}$ & Medr \\
\hline & & & Dried leaves & MEDICINAL: tea, for treating cold & \\
\hline $\begin{array}{l}\text { Rubus schleicheri Weihe ex Tratt. } \\
\text { and other Rubus spp. (Rosaceae) }\end{array}$ & Manaferra & W & Fresh fruits & FOOD: consumed raw; jams & Monca \\
\hline $\begin{array}{l}\text { Rumex acetosella L. } \\
\text { (Polygonaceae) }\end{array}$ & $\begin{array}{l}\text { Gisilica* } \\
\text { Kiselica* }^{*} \\
\text { Kisilica* }^{*}\end{array}$ & W & Fresh and dried leaves & $\begin{array}{l}\text { FOOD: filling for pies (in the past leaves } \\
\text { were dried and stored for the winter, then } \\
\text { rehydrated in water and used as a fresh } \\
\text { vegetable) }\end{array}$ & Gasilica \\
\hline $\begin{array}{l}\text { Rumex patientia } \\
\text { L. (Polygonaceae) }\end{array}$ & Lepçeta & W & Fresh leaves & FOOD: filling for pie (peta) & $\begin{array}{l}\text { Lipgjet FOOD: consumed boiled with/in dhalt } \\
\text { (kind of Albanian buttermilk) }\end{array}$ \\
\hline $\begin{array}{l}\text { Salix alba L. and other Salix } \\
\text { spp. (Salicaceae) }\end{array}$ & Shelçe & W & Fresh branches & $\begin{array}{l}\text { HANDICRAFTS: weaved in diverse kinds } \\
\text { of baskets (kos }{ }^{*} \text { ) }\end{array}$ & $\begin{array}{l}\text { Shelçe MEDICINAL: steam baths for treating } \\
\text { rheumatisms }\end{array}$ \\
\hline Salvia verticillata L. (Lamiaceae) & Gamnash & W & Fresh flowers & $\begin{array}{l}\text { HONEY PLANT: The honey obtained from } \\
\text { bees visiting the plant is considered very } \\
\text { effective against bronchitis }\end{array}$ & \\
\hline Sambucus ebulus L. (Adoxaceae) & $\begin{array}{l}\text { Basdalina* } \\
\text { Shtog i egër }\end{array}$ & W & Fresh leaves & $\begin{array}{l}\text { MEDICINAL: topically applied against } \\
\text { snake bites }\end{array}$ & \\
\hline Sambucus nigra L. (Adoxaceae) & Shtog & W & Flowers & & Shtog \\
\hline
\end{tabular}


Table 1 Folk names and uses of plants and fungi quoted in the current study, compared with those recorded one century ago in the same area (Continued)

\begin{tabular}{|c|c|c|c|c|c|}
\hline & & & & $\begin{array}{l}\text { FOOD/MEDICINAL: syrup }\left(\text { sok }^{*}\right) \text { considered a } \\
\text { cough remedy (expectorant); sometimes } \\
\text { also given to children affected by belly } \\
\text { pains to drink }\end{array}$ & \\
\hline & & & Fresh fruits & FOOD: syrups and jams & \\
\hline & & & Wood & HANDICRAFTS: for building spindles* & \\
\hline Satureja montana L. (Lamiaceae) & Lis & W & Fresh flowers & HONEY PLANT & \\
\hline \multirow[t]{4}{*}{ Secale cereale L. (Poaceae) } & \multirow[t]{2}{*}{ Thekna } & \multirow[t]{2}{*}{ C } & \multirow[t]{2}{*}{ Fruits } & FODDER & \multirow{2}{*}{$\begin{array}{l}\text { Thekn FOOD: kurkurama - gruel made by rye, } \\
\text { corn, wheat and beans }\end{array}$} \\
\hline & & & & FOOD: roasted, as a coffee substitute* & \\
\hline & & & $\begin{array}{l}\text { Dried fruits } \\
\text { (grounded) } \rightarrow \text { Flour }\end{array}$ & $\begin{array}{l}\text { FOOD: in the past used for baking } \\
\text { sourdough bread (bukë çerepi) -prepared } \\
\text { adding dhallët (buttermilk) and fermenting } \\
\text { 2-3 days - and also for pies }\end{array}$ & $\begin{array}{l}\text { FOOD: buk thekninta - sourdough bread; buk e } \\
\text { persiet - sourdough bread made by mixing rye, } \\
\text { wheat, and corn flours }\end{array}$ \\
\hline & & & Dried aerial parts (straw) & $\begin{array}{l}\text { HANDICRAFTS: filling for horse saddles, } \\
\text { pillows and mattresses }\end{array}$ & - \\
\hline Sideritis spp. (Lamiaceae) & Çaj malit & $\begin{array}{l}\text { B (brought from } \\
\text { the town pazar/ } \\
\text { market, } \\
\text { presumably } \\
\text { gathered from } \\
\text { mountainous areas } \\
\text { nearby) }\end{array}$ & $\begin{array}{l}\text { Dried flowering aerial } \\
\text { parts }\end{array}$ & MEDICINAL: tea for treating cold & \\
\hline \multirow[t]{3}{*}{$\begin{array}{l}\text { Solanum tuberosum L. } \\
\text { (Solanaceae) }\end{array}$} & $\begin{array}{l}\text { Repa* } \\
\text { Kompira* }\end{array}$ & C & Tubers & $\begin{array}{l}\text { FOOD: traditionally consumed boiled with } \\
\text { piprik e shtupun (see Capsicum annuum); } \\
\text { fried, or roasted }\end{array}$ & Kampire \\
\hline & & & & $\begin{array}{l}\text { MEDICINAL: slices of a fresh tuber were } \\
\text { externally applied on the forehead for } \\
\text { treating headaches }\end{array}$ & \\
\hline & & & Young leaves & $\begin{array}{l}\text { FOOD: boiled and consumed as vegetables } \\
\text { with buttermilk, or as filling for pies } \\
\text { (especially in the past - however one elderly } \\
\text { couple confirmed that they also consume } \\
\text { them nowadays) }\end{array}$ & \\
\hline Syringa vulgaris L. (Oleaceae) & Ergovan* & $C$ & Flowers & ORNAMENTAL & Ergavan \\
\hline \multirow[t]{3}{*}{ Tanacetum vulgare L. (Asteraceae) } & Vratik $^{*}$ & W & Dried flowering tops & $\begin{array}{l}\text { MEDICINAL: tea, as a digestive; in the past, } \\
\text { the decoctions were externally used for } \\
\text { washing children affected by rubella or } \\
\text { persons affected by hepatitis* - for this last } \\
\text { use sometimes the decoction was also drunk }\end{array}$ & \\
\hline & & & & VETERINARY: considered poisonous for calves & \\
\hline & & & & OTHERS: placed in closets as a moth repellent & \\
\hline $\begin{array}{l}\text { Taraxacum officinale } \\
\text { Weber (Asteraceae) }\end{array}$ & Bastë e egër & W & Fresh leaves & FOOD: eaten in spring salads & \\
\hline
\end{tabular}


Table 1 Folk names and uses of plants and fungi quoted in the current study, compared with those recorded one century ago in the same area (Continued)

\begin{tabular}{|c|c|c|c|c|c|}
\hline Thymus serpyllum L. (s.l.) & \multirow{2}{*}{$\begin{array}{l}\text { Lis Majçina } \\
\text { dushnica* }\end{array}$} & \multirow[t]{2}{*}{ W } & \multirow[t]{2}{*}{ Aerial parts } & \multirow[t]{2}{*}{ MEDICINAL: tea, for treating cold and cough } & \\
\hline \multirow[t]{2}{*}{ (Lamiaceae) } & & & & & \\
\hline & & & Fresh flowers & HONEY PLANT & \\
\hline \multirow[t]{3}{*}{ Tilia cordata Mill. (Malvaceae) } & Lipa* $^{*}$ & SD & Dried inflorescences & MEDICINAL: tea, for treating colds & Blini \\
\hline & & & Fresh flowers & HONEY PLANT & \\
\hline & & & $\operatorname{Resin}\left(s m o{ }^{*}\right)$ & $\begin{array}{l}\text { MEDICINAL: externally applied to skin } \\
\text { inflammations }\end{array}$ & \\
\hline \multirow[t]{2}{*}{ Trifolium spp. (Fabaceae) } & Detelina* & W & Fresh flowers & HONEY PLANT; & Trfonj \\
\hline & & & & $\begin{array}{l}\text { FODDER: for cows, it is considered a } \\
\text { galactagogue (promoting milk production) }\end{array}$ & \\
\hline $\begin{array}{l}\text { Trigonella foenum-graecum L. } \\
\text { (Fabaceae) }\end{array}$ & Gruni piprikes & C & Dried aerial parts & $\begin{array}{l}\text { FOOD: as an ingredient of the seasoning } \\
\text { mix piprik e shtupun (see Capsicum annuum) }\end{array}$ & \\
\hline \multirow[t]{2}{*}{ Triticum aestivum L. (Poaceae) } & Grur & C & Fruits & FOOD & $\begin{array}{l}\text { Gruni FOOD: kukurama - gruel made by rye, } \\
\text { corn, wheat and beans }\end{array}$ \\
\hline & & & Fruits (ground) $\rightarrow$ Flour & FOOD: bread and pies & $\begin{array}{l}\text { FOOD: buk e ngjeshun - leavened bread; buk } \\
\text { grunit - sourdough bread; buk e persiet - bread } \\
\text { obtained mixing corn, rye, and wheat flours } \\
\text { peçiv - kind of crusty bread, with a buttered } \\
\text { inner part fli - a kind of crusty bread, made by } \\
\text { several alternate layers of dough and butter, } \\
\text { each layer is baked in sequence; koleç - bread } \\
\text { made by diverse little bread units; ndurdhi - like } \\
\text { fli, but with thicker layers, which are broken and } \\
\text { finally dipped with melted butter bosa - a } \\
\text { lacto-fermented beverage made with wheat } \\
\text { flour, mixed with millet flour (or maize flour), } \\
\text { which was boiled in water approx. } 12 \text { hrs.; the } \\
\text { resulting mass was then knitted by hands and, } \\
\text { after the adding of yeast, kept overnight, until it } \\
\text { was dissolved in water; in the upper Reka, } \\
\text { young men used to migrate to town as bosa } \\
\text { producers and vendors in the Ottoman Empire }\end{array}$ \\
\hline \multirow[t]{2}{*}{$\begin{array}{l}\text { Vaccinium myrtillus } \\
\text { L. (Ericaceae) }\end{array}$} & $\begin{array}{l}\text { Shurshia të egra } \\
\text { Baruk } \\
\text { Borovnica* }\end{array}$ & W & Fresh fruits & $\begin{array}{l}\text { FOOD/MEDICINAL: consumed raw, and } \\
\text { sometimes believed to be "healthy for the } \\
\text { blood"; syrups and jams; the fresh fruits are } \\
\text { nowadays gathered in the summertime in } \\
\text { large amounts and sold to middle men } \\
\text { from Gostivar }\end{array}$ & Qyrshiat t egra \\
\hline & & & Dried leaves & MEDICINAL: tea, used for heart problems & \\
\hline $\begin{array}{l}\text { Veratrum album L. } \\
\text { (Melanthiaceae) }\end{array}$ & Shtarë & W & Roots & $\begin{array}{l}\text { VETERINARY: decoctions, in external washes } \\
\text { for treating lice in animals; root inserted in } \\
\text { the horse's breast for treating muscular } \\
\text { blocks (horses can't be ridden anymore) }\end{array}$ & $\begin{array}{l}\text { Shtar VETERINARY: decoction of the roots was } \\
\text { used for treating scabies in sheep }\end{array}$ \\
\hline
\end{tabular}


Table 1 Folk names and uses of plants and fungi quoted in the current study, compared with those recorded one century ago in the same area (Continued)

\begin{tabular}{|c|c|c|c|c|c|}
\hline & & & Fresh leaves & $\begin{array}{l}\text { VETERINARY: considered poisonous if } \\
\text { animals consume them in large amounts } \\
\text { (foaming at the mouth) }\end{array}$ & $\begin{array}{l}\text { VETERINARY: Consuming large amounts of the } \\
\text { leaves of the same plant was considered } \\
\text { poisonous in sheep (foaming at the mouth), } \\
\text { even very rarely lethal }\end{array}$ \\
\hline & & & Dried leaves & OTHERS: smoked as tobacco substitute & \\
\hline \multirow{2}{*}{$\begin{array}{l}\text { Verbascum thapsus L. } \\
\text { (Scrophulariaceae) }\end{array}$} & \multirow{2}{*}{$\begin{array}{l}\text { Bubujak } \\
\text { Brusla }\end{array}$} & \multirow[t]{2}{*}{ W } & \multirow[t]{2}{*}{ Fresh leaves } & MEDICINAL: externally as an haemostatic & \multirow[t]{2}{*}{ Bubujak } \\
\hline & & & & $\begin{array}{l}\text { OTHERS: used for covering butter, peppers } \\
\text { with ricotta cheese, or lacto-fermented } \\
\text { vegetables }\end{array}$ & \\
\hline \multirow[t]{3}{*}{ Urtica dioica L. (Urticaceae) } & \multirow[t]{3}{*}{ Kapriva* } & \multirow[t]{3}{*}{ W } & Fresh leaves & $\begin{array}{l}\text { FOOD/MEDICINAL: consumed boiled (also in } \\
\text { the past mixed with sorrel and potato } \\
\text { leaves) or in soups, or as filling for savory } \\
\text { pies - consumption of nettle is considered } \\
\text { healthy as a "blood depurative" } \\
\text { MEDICINAL: externally rubbed for treating } \\
\text { rheumatisms }\end{array}$ & Kopriva \\
\hline & & & \multirow[t]{2}{*}{ Roots } & FOOD: used in the past as rennet & \\
\hline & & & & $\begin{array}{l}\text { MEDICINAL: decoctions are considered able } \\
\text { to treat cancer and especially to relieve liver } \\
\text { problems (decoction of the leaves and roots } \\
\text { together) }\end{array}$ & \\
\hline \multirow[t]{4}{*}{ Zea mays L. (Poaceae) } & $\begin{array}{l}\text { Çenk } \\
\text { Kolomoç } \\
\text { Barsak }\end{array}$ & $\begin{array}{l}C \text { (white and } \\
\text { yellow landraces) }\end{array}$ & Fruits & FODDER & $\begin{array}{l}\text { Mçenk Kalamoç FOOD: kukurama - gruel made } \\
\text { by rye, corn, wheat and beans }\end{array}$ \\
\hline & & & $\begin{array}{l}\text { Dried fruits } \\
\text { (ground) } \rightarrow \text { Flour }\end{array}$ & $\begin{array}{l}\text { FOOD: buk kolomoçit - bread (traditionally } \\
\text { leavened with buttermilk [dhallët]); } \\
\text { ingredient of the seasoning mix bagrdar - } \\
\text { polenta obtained boiling the flour for at } \\
\text { least one hour on the fire, generally served } \\
\text { with buttermilk (dhallët), or clarified butter } \\
\text { (tlynë) or yogurt (kos) - esp. ewe yogurt (kos } \\
\text { delje); alternatively, polenta is served with } \\
\text { beans or potato soup; pies (peta), filled with } \\
\text { various vegetables }\end{array}$ & $\begin{array}{l}\text { FOOD: buk mçenkut - bread; buk pervlue - } \\
\text { sourdough bread; pershenik- leavened bread; } \\
\text { pershesh - pershenik dipped in buttermilk [dhalt] } \\
\text { or yogurt [kos]) mçenka (like kukurama, but } \\
\text { prepared with corn only); bagrdar or kaçamak } \\
\text { me tlynë - polenta served with clarified butter }\end{array}$ \\
\hline & & & & FODDER & \\
\hline & & & & $\begin{array}{l}\text { RITUAL: corn flour was brought to the } \\
\text { Islamic spiritual guide (hoxha), who "wrote" } \\
\text { something with this; this was considered } \\
\text { essential for treating the evil eye of a } \\
\text { member of the family }\end{array}$ & \\
\hline Various herbaceous species & & W & Fresh stem & $\begin{array}{l}\text { MEDICINAL: inserted into the anus, as a } \\
\text { purgative }\end{array}$ & \\
\hline
\end{tabular}


Table 1 Folk names and uses of plants and fungi quoted in the current study, compared with those recorded one century ago in the same area (Continued)

\begin{tabular}{|c|c|c|c|c|}
\hline \multirow[t]{2}{*}{ Various tree species } & & W & $\begin{array}{l}\text { Wood (burned) } \\
\rightarrow \text { Charcoal }\end{array}$ & $\begin{array}{l}\text { MEDICINAL: used in the past in the ritual } \\
\text { healing of the evil-eye: three pieces of hot } \\
\text { coals were put in cold water; with the } \\
\text { resulting water child face was washed } \\
\text { (generally it has to be done by the first-born } \\
\text { for his/her brothers/sisters; the first-born has } \\
\text { to be treated by a neighbour) and the same } \\
\text { water had to be drunk by the child or } \\
\text { animal; depending on how the coal was } \\
\text { dipped into water, this was also used for the } \\
\text { diagnosis of the evil-eye - sometimes the } \\
\text { water was given to the child in three } \\
\text { spoons, which were then thrown behind } \\
\text { the back; depending on how the spoons fell } \\
\text { on the ground, the occurrence of the evil- } \\
\text { eye was confirmed }\end{array}$ \\
\hline & & & Ash & OTHERS: for washing clothes \\
\hline Not identified & Ferra magjara & W & Leaves & FODDER: for donkeys \\
\hline Not identified & Kulosgjarpni & W & Fresh flowers & $\begin{array}{l}\text { VETERINARY: applied externally against snake } \\
\text { bites in horses }\end{array}$ \\
\hline Not identified & Morava* & W & Leaves & FOOD: filling for savory pies \\
\hline
\end{tabular}

for his/ly it has to be done by the first-born

or his/her brothers/sisters; the first-born has

* Recorded local phytonyms, names of plant parts or plant preparations, which have been recorded also among South Slavs (even if the etymology may not be always Slavic; according to [22,34-44]); B: bought; C: cultivated; SD: semi-domesticated (not cultivated), but in some way "managed"; W: wild. 


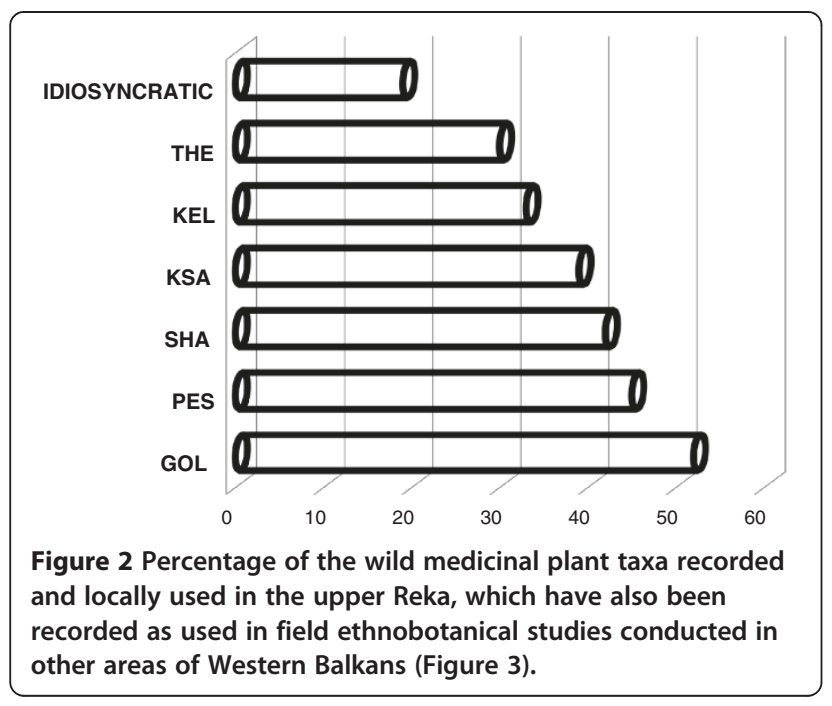

past and partially today, however a local use of gentian is unknown. Vice-versa, the use of hellebore in local ethnoveterinary practices may be very ancient; it was used mainly as external/topical agent for treating lice in diverse animals and especially for healing horses (roots were inserted into the musculature of the horse breast). This perhaps suggests that the gathering of Veratrum album in the Albanian mountains preceded the gathering of gentian, which could have been introduced by "external" factors: other cultures, such as the contiguous Slav ones, where the folk uses of gentian are widespread [1,4-7], or by the demands of urban markets.

\section{Cross-cultural comparison}

Figure 2 shows that a relevant portion of the medicinal plant taxa recorded and used in the upper Reka Valley are also part of the folk medical heritage of surrounding Balkan regions, where other field ethnobotanical surveys have been recently conducted (Figure 3).

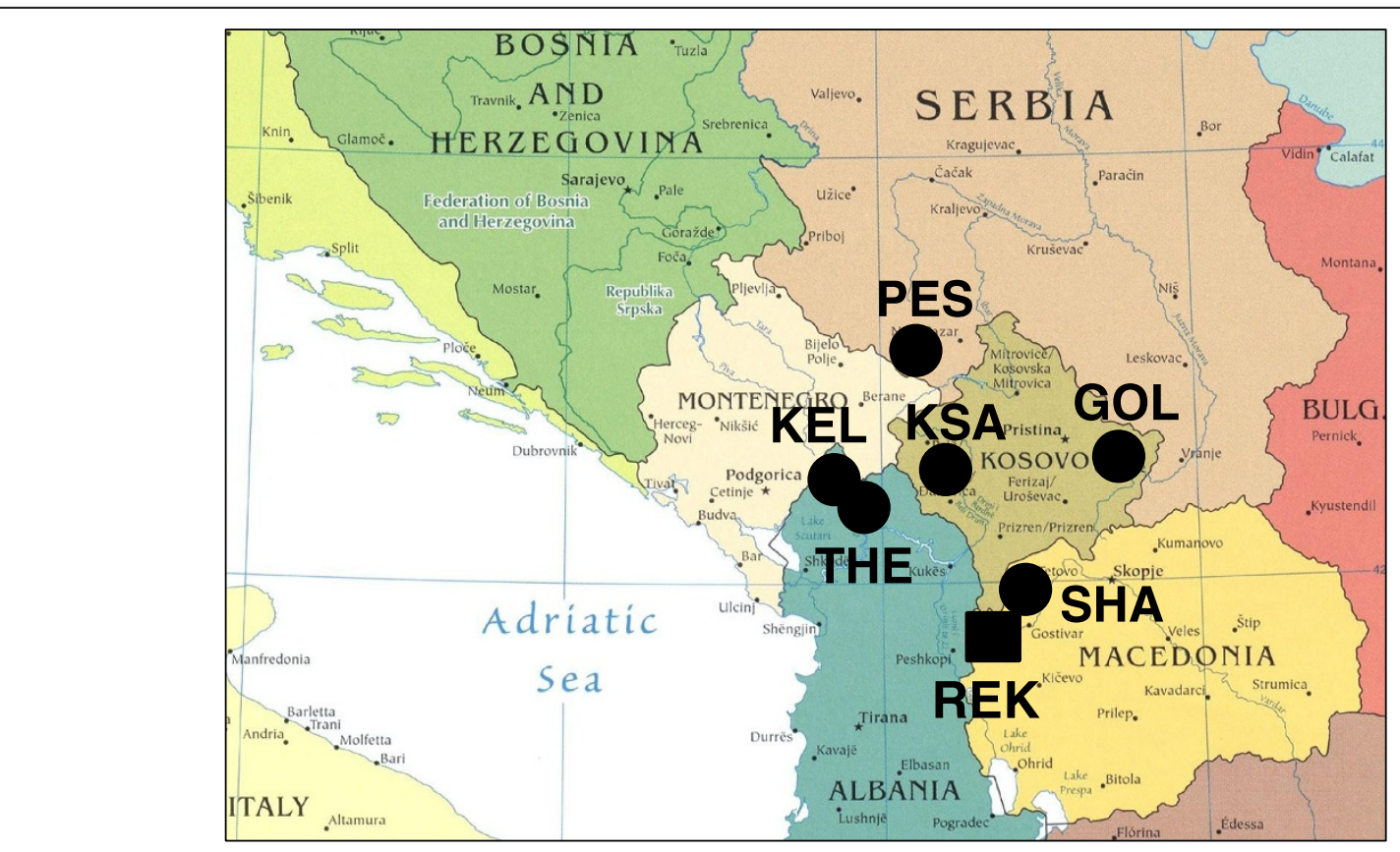

KEL=Kelmend, Northern Albania

GOL=Gollak, Kosovo

PES=Pešter plateau, SW Serbia

REK=upper Reka Valley (present study)

KSA=Albanian Alps, Kosovo

SHA=Sharr Mountains, Western Macedonia

THE=Theth, Northern Albania

Figure 3 Location of the Western Balkan areas, where the ethnobotanical studies used for the comparative analysis have been recently conducted. 
Table 2 Food, medicinal, and other domestic uses of non-indigenous plants, and animal, mineral, and industrial products quoted in the study area

\begin{tabular}{|c|c|}
\hline Product (local name) & Local use \\
\hline Animal rennet (stomach of very young animals) (sirisht) & Used for producing cheese, but also as a starter for making yogurt\#; anti-diarrheal \\
\hline Ants & Used in the past as a rennet substitute\# \\
\hline Bear's fat & Used externally for treating rheumatisms\# \\
\hline Beer & One glass of beer, drunk, is considered healthy for the kidney \\
\hline Black piece of cloth & Tied onto cow's neck or horns, as a protective amulet against evil eye\# \\
\hline Bullet & Attached to clothes and worn as a protective amulet against evil eye\# \\
\hline Buttermilk (dhallët) & $\begin{array}{l}\text { Drunk as a post-partum reconstituent or for treating intestinal troubles and } \\
\text { hypertension; used as starter for producing home-made yogurt }\end{array}$ \\
\hline Chicken & $\begin{array}{l}\text { Cooked for a long time, until obtaining a gelatinous material, which is further } \\
\text { cooked together with onions, corn flour and vinegar to create home-made soap\# }\end{array}$ \\
\hline Clarified butter (tlynë) & Drunk for treating hypotension \\
\hline Clothes dressed on the wrong side & Protective amulet against evil eye\# \\
\hline Coffee powder & $\begin{array}{l}\text { Spoonful is ingested for treating hypotension; decoction ("Turkish coffee") for } \\
\text { hypotension; externally applied to cuts }\end{array}$ \\
\hline Copper sulphate & Used externally for healing lameness in sheep\# \\
\hline Cow's milk & Drunk in cases of constipation \\
\hline Cut & $\begin{array}{l}\text { Cutting the ewe's ear and letting blood coming out was considered an effective } \\
\text { method for treating several sheep diseases\# }\end{array}$ \\
\hline Dried sheep and cow's faeces & Burned, the resulting smoke keeps the bees away while taking honey\# \\
\hline Goat milk & Applied (warm) into the ear against earache\# \\
\hline Gunpowder (barut) & $\begin{array}{l}\text { Its odour is exposed to the nose of sleepwalkers, in order to bring them back to } \\
\text { consciousness\#; odour was also considered a repellent for werewolves\# }\end{array}$ \\
\hline Hare's meat & If consumed, believed to inhibit fertility\# \\
\hline Honey (mjalt) & $\begin{array}{l}\text { Consumed for improving blood circulation or as a post-partum reconstituent: } \\
\text { Ingested for treating sore throats }\end{array}$ \\
\hline Knife & A knife placed under the pillow is considered preventive for sleepwalking\# \\
\hline Leech & Applied externally for "sucking the bad blood"\# \\
\hline Lemon & $\begin{array}{l}\text { Drunk to treat hypertension; sometimes used in the past as rennet for making } \\
\text { cheese\# }\end{array}$ \\
\hline Match's head & Topically applied for treating toothaches\# \\
\hline Mother's milk & Instilled in the ear for treating inflammations/earache \\
\hline Mud & Applied onto bee stings for pain relief\# \\
\hline Oil & Ingested to treat constipation \\
\hline Pork fat & Externally used on burns\# \\
\hline Propolis & $\begin{array}{l}\text { Tea or macerate in raki used for treating cough/respiratory problems and } \\
\text { intestinal discomforts (all of which are considered "new" uses) }\end{array}$ \\
\hline Ricotta cheese (gjizë) & Consumed, is considered "good for the blood" \\
\hline Royal gelly & Consumed for improving mental faculties ("new" use) \\
\hline \multirow[t]{2}{*}{ Salt } & $\begin{array}{l}\text { Brought to the Islamic spiritual guide (hoxha), who "wrote something" with this\#- } \\
\text { this was considered essential for treating the evil eye of a member of the family; } \\
\text { mixed with water, and the resulting solution instilled in the ear or eye for treating } \\
\text { inflammations; mixed with hot water in external bathes for treating chilblains; }\end{array}$ \\
\hline & Applied topically for treating toothache \\
\hline Soap & A small piece inserted in the anus, as a purgative\# \\
\hline Snow & Applied on the feet for relieving arthritic pains \\
\hline Starch & Ingested for treating diarrhoea \\
\hline Stone & Pressed on skin zone affected by the bee bite, in order to relieve the pain \\
\hline Sugar & $\begin{array}{l}\text { Externally applied to cuts; mixed with water (sherbet) for treating stomach-ache; } \\
\text { burned and ingested considered a medicine for sore throats }\end{array}$ \\
\hline Tobacco & Haemostatic \\
\hline
\end{tabular}


Table 2 Food, medicinal, and other domestic uses of non-indigenous plants, and animal, mineral, and industrial products quoted in the study area (Continued)

\begin{tabular}{ll}
\hline Urin (human urine) & Externally applied on cuts\#; drunk against hepatitis\# \\
\hline $\begin{array}{l}\text { Vinegar from honey (uthull dëgjetes) - produced at home } \\
\text { fermenting in water honey and raw wax for a couple of weeks }\end{array}$ & $\begin{array}{l}\text { Used as rennet\#; Externally applied on the front or feet for treating fever; applied } \\
\text { on the chest for treating bronchitis; applied on the belly of babies when crying } \\
\text { or colicky }\end{array}$ \\
\hline Yogurt (kos) & Post-partum reconstituent \\
\hline Water & $\begin{array}{l}\text { Drunk against high blood pressure; Fumigations of hot water (eventually heated } \\
\text { by previously heated stone) for treating cold }\end{array}$ \\
\hline Whey (hirra) & Drunk as a diuretic, or against hypertension, or "to decrease fats in the blood" \\
\hline Wool & Raw sheep wool externally applied for treating bruises\#
\end{tabular}

\# remembered, but nowadays disappeared use(s).

This is especially true in those areas where the Albanian population was historically in extensive contact with the South-Slavic cultures, such as the Gollak area in eastern Kosovo [9], the Pešter plateau in south-western Serbia [1] and the Sharr Mountain (Šar Planina in Macedonian) in western Macedonia [29] (Figure 3).

This may confirm the findings of both our linguistic analysis on the folk plant names carried out in Table 1 and also Franz Nopcsa's ethnolinguistic analysis of the terms referring to the material culture in upper Reka [22], which showed very important loans from the Romanian and especially Slavic languages. It can thus be postulated that the upper Reka Albanians had been heavily influenced by the Slavic culture - and not vice-versa, as Spiridon Gopčević stated [23].

Study participants confirmed that over recent decades their most important markets and "exchange" centres have been the multi-ethnic (Macedonian, Albanian, and Turk) towns of Gostivar in Western Macedonia and Prizren, in Southern Kosovo. Moreover, it must also be noted that over the span of the last century, the Albanians of the upper Reka lived outside of the borders of the Albanian state (founded in 1912), and for the major part of this period within the former Socialist Republic of Macedonia within Yugoslavia, where the dominant culture and languages have been Macedonian and Serbo-Croatian. In other words, the remarkable "interference" of the Slavic cultures found within the domain of Albanian traditional plant knowledge of the upper Reka represents a unique phenomenon, which nowadays is not easy to trace back in detail. This could be due to the difficulty faced in establishing to which degree the Slavic culture influenced the traditional knowledge among Albanians in the upper Reka, considering the role that ancient "hybridisations" may have played, as both Gopčević and Nopcsa, although in a different way, have underlined in their respective works.

Moreover, as well analysed by Fredrick Barth more than four decades ago [46], cultural contacts and boundaries among ethnic groups may be very complex and subject to dynamic change, since they respond to very unique societal and historical circumstances. It could be interesting to follow the future development of local perceptions of nature among the last remaining Albanians of the upper Reka and the strategies that they will adopt through processes of further negotiation of their identities within the rest of the population in Western Macedonia and the whole country.

\section{Other domestic remedies}

Table 2 reports other domestic and medicinal remedies recorded in the area, which are not based on indigenous plants; a large portion of these remedies survives only in the memories of the interviewees.

\section{Conclusions}

The very few last remaining Albanians living on the Macedonian side of Mount Korab of the upper Reka still retain a remarkable level of local knowledge concerning botanicals; this knowledge is however eroded, especially in quantitative terms, due the very tiny population, who have decided to remain in the region despite the influence of economic hardships. The hybrid "Albanian-Slav" cultural features of the local inhabitants, which have been largely discussed and disputed in Balkanological studies, could be confirmed in our ethnobotanical surveys, since both local plant names and especially a significant portion of the recorded plant uses share common features with other Slavic and culturally mixed areas of the Western Balkans. The multi-faceted knowledge recorded here could represent a crucial added value for the local managers of the Mavrovo National Park and also for further fostering new forms of eco-tourism, which must be sensitive not only to local biodiversity, but also to the multi-cultural dimension of a historically complex area like the upper Reka.

\section{Competing interests}

The authors declare that they have no competing interests.

\section{Authors' contributions}

AP designed the research and conducted the historical and field studies; BR assisted in the field study; AN, VK, and HA contributed to the ethnolinguistic and cross-cultural comparative analysis of the data; AN, HA, BM, and KC 
analysed the botanical taxonomic part of the data; AP and CLQ drafted the overall scientific discussion. All authors read and approved the final manuscript.

\section{Acknowledgments}

Special thanks are due to all of the inhabitants of the upper Reka, and especially to the Elvir Bilalli and his family (Nistrovë) for their wonderful field assistance, generosity and friendship; to Alessandro Scalerandi for the video documentation of the field study; to Ludovico Roccatello and Alessando di Tizio for the logistic assistance in the field; to the reviewers, for their precious comments; to the University of Gastronomic Sciences, Pollenzo, Italy, for having funded the field study.

This article is dedicated to the memory of Professor Sulejman Redzic, University of Sarajevo, plant ecologist and ethnobotanist, unforgettable, passionate colleague, who passed away in January 2013.

\section{Author details}

'University of Gastronomic Sciences, Piazza Vittorio Emanuele 9, Pollenzo/Bra, (Cuneo) I-12042, Italy. 'Department of Biology, State University of Tetova, Ilindenska, Tetovë, Republic of Macedonia. ${ }^{3}$ Department of Botany, University of Sofia, Blv. Dragan Tzankov 8, Sofia 1164, Bulgaria. ${ }^{4}$ Department of Biology, University of Prishtina "Hasan Prishtina", Mother Teresa Str, Prishtinë 10000 , Republic of Kosovo. ${ }^{5}$ Institute for Linguistic Studies, Russian Academy of Sciences, Tuchkov pereulok 9, Saint Petersburg 199053, Russia. ${ }^{6}$ School of Environmental Sciences, University of Camerino, Via Pontoni 5, Camerino (Macerata) 1-62032, Italy. ${ }^{7}$ Center for the Study of Human Health, Emory University, 550 Asbury Circle, Candler Library 107E, Atlanta, GA 30322, USA.

Received: 4 March 2013 Accepted: 4 April 2013

Published: 11 April 2013

\section{References}

1. Pieroni A, Giusti ME, Quave CL: Cross-Cultural Ethnobiology in the Western Balkans: Medical Ethnobotany and Ethnozoology Among Albanians and Serbs in the Pešter Plateau, Sandžak, South-Western Serbia. Hum Ecol 2011, 39(3):333-349.

2. Redzic S: Wild medicinal plants and their usage in traditional human therapy (Southern Bosnia and Herzegovina, W. Balkan). J Med Plant Res 2010, 4(11):1003-1027.

3. Redžić S: Wild edible plants and their traditional use in the human nutrition in Bosnia and Herzegovina. Ecol Food Nutr 2006, 45:189-232.

4. Šarić-Kundalić B, Dobeš C, Klatte-Asselmeyer V, Saukel J: Ethnobotanical survey of traditionally used plants in human therapy of east, north and north-east Bosnia and Herzegovina. J Ethnopharmacol 2011, 133(3):1051-1076.

5. Šarić-Kundalić B, Dobeš C, Klatte-Asselmeyer V, Saukel J: Ethnobotanical study on medicinal use of wild and cultivated plants in middle, south and west Bosnia and Herzegovina. J Ethnopharmacol 2010, 131(1):33-55.

6. Jarić S, Popović Z, Mačukanović-Jocić M, Djurdjević L, Mijatović M, Karadžić $B$, Mitrović M, Pavlović P: An ethnobotanical study on the usage of wild medicinal herbs from Kopaonik Mountain (Central Serbia). J

Ethnopharmacol 2007, 111(1):160-175.

7. Menković N, Šavikin K, Tasić S, Zdunić G, Stešević D, Milosavljević S, Vincek D: Ethnobotanical study on traditional uses of wild medicinal plants in Prokletije Mountains (Montenegro). J Ethnopharmacol 2011, 133(1):97-107.

8. Mustafa B, Hajdari A, Krasniqi F, Hoxha E, Ademi H, Quave CL, Pieroni A: Medical ethnobotany of the Albanian Alps in Kosovo. J Ethnobiol Ethnomed 2012, 8:6.

9. Mustafa B, Hajdari A, Pajazita Q, Syla B, Quave CL, Pieroni A: An ethnobotanical survey of the Gollak region, Kosovo. Genetic Resources and Crop Evolution 2011, 16:1-16.

10. Pieroni A, Dibra B, Grishaj G, Grishaj I, Maçai SG: Traditional phytotherapy of the Albanians of Lepushe Northern Albanian Alps. Fitoterapia 2005, 76(3-4):379-399.

11. Redzic S: Wild Mushrooms and Lichens used as Human Food for Survival in War Conditions; Podrinje - Zepa Region (Bosnia and Herzegovina, W. Balkan). Hum Ecol Rev 2010, 17(2):175-187.

12. Redzic S: The ecological approach to ethnobotany and ehnopharmacology of population in Bosnia and Herzegovina. Collegium Antropol 2007, 31:869-890.

13. Pieroni A: Local plant resources in the ethnobotany of Theth, a village in the Northern Albanian Alps. Genet Resour Crop Ev 2008, 55(8):1197-1214.
14. Luczaj L: Changes in the utilization of wild green vegetables in Poland since the 19th century: a comparison of four ethnobotanical surveys. J Ethnopharmacol 2010, 128(2):395-404.

15. Luczaj L: Archival data on wild food plants used in Poland in 1948. J Ethnobiol Ethnomed 2008, 4:4.

16. Luczaj L, Szymanski WM: Wild vascular plants gathered for consumption in the Polish countryside: a review. J Ethnobiol Ethnomed 2007, 3:17.

17. Soukand R, Kalle R: Change in medical plant use in Estonian ethnomedicine: a historical comparison between 1888 and 1994. J Ethnopharmacol 2011, 135(2):251-260.

18. Soukand R, Kalle R: The use of teetaimed in Estonia, 1880s-1990s. Appetite 2012, 59(2):523-530.

19. Leonti M: The future is written: impact of scripts on the cognition, selection, knowledge and transmission of medicinal plant use and its implications for ethnobotany and ethnopharmacology. J Ethnopharmacol 2011, 134(3):542-555.

20. Leonti M, Cabras S, Weckerle CS, Solinas MN, Casu L: The causal dependence of present plant knowledge on herbals - Contemporary medicinal plant use in Campania (Italy) compared to Matthioli (1568) J Ethnopharmacol 2010, 130(2):379-391.

21. Leonti M, Casu L, Sanna F, Bonsignore L: A comparison of medicinal plant use in Sardinia and Sicily-De Materia Medica revisited? J Ethnopharmacol 2009, 121(2):255-267.

22. Doda BE, Nopcsa F: Albanisches Bauernleben in oberen Rekatal dei Dibra (Makedonien). Vienna: LIT; 2007.

23. Gopčević S: Makedonien und Alt-Serbien. Vienna: von L.W. Seidel \& Sohn; 1889.

24. American Anthropological Association: Statement on Ethics: Principles of Professional Responsability. http://www.aaanet.org/profdev/ethics/upload/ Statement-on-Ethics-Principles-of-Professional-Responsibility.pdf.

25. Scalerandi A: Correspondences. http://vimeo.com/63083584.

26. Tutin T, Heywood V, Burges N, Valentine D, Walters S, Webb D: Flora Europaea. Cambridge, UK: University Press; 1964-1994.

27. Stevens PF: Angiosperm Phylogeny Website, Version 12. 2012. http://www. mobot.org/MOBOT/research/APweb.

28. The Plant List: The Plant List, version 1. 2010. http://www.theplantlist.org.

29. Rexhepi B, Mustafa B, Hajdari A, Rushidi-Rexhepi J, Quave CL, Pieroni A: Traditional medicinal plant knowledge among Albanians, Macedonians and Gorani in the Sharr Mountains (Republic of Macedonia). Genet Resour Crop Ev 2013. doi:10.1007/s10722-013-9974-3.

30. Nedelcheva AM, Dogan Y, Guarrera PM: Plants traditionally used to make brooms in several European countries. J Ethnobiol Ethnomed 2007, 3:20.

31. Dogan Y, Nedelcheva AM, Obratov-Petković D, Padure IM: Plants used in traditional handicrafts in several Balkan countries. Indian J Trad Know 2008, 7(1):157-161.

32. Nedelcheva A, Dogan Y: Usage of plants for weather and climate forecasting in Bulgarian folk traditions. Indian J Trad Know 2011, 10(1):91-95.

33. Nedelcheva A, Dogan Y, Obratov-Petkovic D, Padure IM: The Traditional Use of Plants for Handicrafts in Southeastern Europe. Hum Ecol 2011, 39(6):813-828.

34. Josifović M: Flora SR Srbije (1-9) [Flora of Socialist Republic of Serbia]. Belgrade: Srpska akademija nauka i umetnosti; 1970-1977.

35. Ahtarov B, Davidov B, Yavashev A: Materiali za Balgarski botanichen rechnik [Materials for the Bulgarian botanical glossary]. Balgarska Akademia na Naukite, Pridvorna Pechatnitsa: Sofia; 1939.

36. Georgiev VI: Balgarski etimologichen rechnik [Bulgarian etymological dictionary]. Sofia: BAN; 1971.

37. Trubachëv ON: ESSJA Etimologicheskii slovar' slavianskikh iazykov [Etymological dictionary of the Slavic languages]. Moskow: Nauka; 1974.

38. Williams G, Hunyadi K: Dictionary of weeds of Eastern Europe - The common names and importance in Latin, Albanian, Bulgarian, Czech, German, English, Greek, Hungarian,Polish, Romanian, Russian, Serbo-Croat and Slovak. Amsterdam: Elsevier; 1987.

39. Simonović D: Botanichki rechnik. Imena biljaka sa imenima na ruskom, angleskom, nemachkon i frantsuskom jeziku [Botanical dictionary. Names of plants with in Russian, English, German, and French]. Nauchno delo: Belgrade; 1959.

40. Škaljić A: Turcizmi u srpskohrvatskom jeziku [Turkisms in the Serbo-Croatian language]. Sarajevo: Svjetlost; 1966.

41. Skok P: Etimologijski rječnik hrvatskoga ili srpskoga jezika [Etymological dictionary of the Croatian or Serbian language]. Zagreb: Jugoslavenska Akademia Znanosti i Umjetnosti; 1971-1988. 
42. Selishchev AM: Slavyanskoe naselenie v Albanii [Slavic population in Albania]. Sofia: Izdanie Makedonskogo Nauchnogo Instituta; 1931.

43. Selishchev AM: Polog i ego bolgarskoe naselenie. Istoricheskie, etnograficheskie I dialektologicheskie ocherki severozapadnoi Makedonii [Polog and its Bulgarian population. Historical, ethnographical and dialectological essay in northwestern Macedonia]. Sofia: Izdanie Makedonskogo Nauchnogo Instituta; 1929.

44. Nedelcheva A, Dogan Y: Folk botanical nomenclature and classification in Bulgarian traditional knowledge. In Plants and Culture: seeds of the cultural heritage of Europe. Edited by Mercuri AM. Bari: Edipuglia; 2009:169-173.

45. Pieroni A, Nebel S, Quave C, Munz H, Heinrich M: Ethnopharmacology of liakra: traditional weedy vegetables of the Arbereshe of the Vulture area in southern Italy. J Ethnopharmacol 2002, 81(2):165-185.

46. Barth F: Introduction. In Ethnic Groups and Boundaries: The Social Organisation of Cultural Difference. Edited by Barth F. Long Grove, Illinois, USA: Waveland Press: 1969:9-38.

doi:10.1186/1746-4269-9-22

Cite this article as: Pieroni et al:: One century later: the folk botanical knowledge of the last remaining Albanians of the upper Reka Valley,

Mount Korab, Western Macedonia. Journal of Ethnobiology and

Ethnomedicine 2013 9:22.

\section{Submit your next manuscript to BioMed Central and take full advantage of:}

- Convenient online submission

- Thorough peer review

- No space constraints or color figure charges

- Immediate publication on acceptance

- Inclusion in PubMed, CAS, Scopus and Google Scholar

- Research which is freely available for redistribution 